compelled the closing of the discussion, it was with regret that members left so vigorous a debate on so vital a topic.

The final paper described the past history and the present policy and aims of the Association's journal, The Mathematical Gazette ; in this address, the editor, Mr. T. A. A. Broadbent, referred particularly to the great work done for the Association by his predecessor, Mr. W. J. Greenstreet, editor of the Gazette for more than thirty years.

The Teaching Committee of the Association, at its general meeting on April 26, paid much attention to the subject of the 'modern' school ; the Committee is anxious that every aspect of mathematical teaching in such schools should be thoroughly surveyed, and that all information and opinion on this topic should be carefully studied. A strong sub-committee has been set up, charged with the duty of making a full and thorough investigation into, and a report to the full Committee on, this vital and urgent problem of mathematical teaching.

\section{FLORA OF EGYPT}

T HAT Egypt is 'the gift of the Nile' may be true from the point of view of human civilization but such a phrase would be misleading if applied to the plant-life of the country. Even the weed flora of the canals and cultivated land is not uniform, and to this must be added the ephemeral flora of the deserts, and the mountains and mountain valleys of Sinai and the Elba mountains. Many botanists have explored Egypt and much has been published regarding both the wild and cultivated flora. However, the need for an accurate and up-to-date taxonomic account cannot be gainsaid, and the present work* by Mrs. Täckholm and the late Prof. G. Täckholm is intended to meet this need.

The first volume (dated 1941) is a mine of information concerning the Pteridophyta, Gymnospermæ, and, following Engler's classification, the monocotyledon families from Typhaceæ to Gramineæ, recorded. in the wild or in cultivation within the political boundaries of Egypt. The descriptions given are short, but there are keys to genera within the families and to the species of the larger genera. The known distribution within Egypt is given very fully with the general distribution in outline. There are a large number of habitat notes and very full bibliographical references.

Particular attention should be directed to two or three special features, some of which are very exceptional, or even unique, in a Flora. All plants known to be cultivated, agriculturally or horticulturally, in Egypt are included, often with very full accounts and numerous extracts, references, and comments. The account of the sugar cane, for example, occupies thirteen pages. The 'tomb flora' is also dealt with at length, with detailed documentation for the families included in this first volume. Thus the wheat of Ancient Egypt is discussed at lengthforty-three pages are devoted to the genus Triticum altogether.

One cannot help feeling that the fundamental purpose of a Flora-for use in determining quickly and accurately the names of plants growing in the

* Flora of Egypt, vol. 1. By Vivi and Gunnar Tăckholm, in collaboration with Mohammed Drar. Cairo: Fouad I University, Bull. Fac. Sci., No. 17, pp. 574 (1941). area covered-is here overwhelmed by the results of most diligent and energetic bibliographical research. This first volume, of 574 pages, only includes probably somewhere about one tenth of the species of vascular plants growing in Egypt. The completion of the Flora on the same scale and to the same standard will make a bulky work. It would appear to the reviewer that a completed one- or two-volume work restricted to the wild flora and its taxonomy would better have met immediate needs and this could then have been followed by as many special volumes as were needed to deal with the cultivated plants, the tomb flora, and so on, as at great a length as the authors thought necessary. It seems a mistake to combine a 'Flora of Egypt' with an 'encyclopedia of Egyptian botany'. The result will be a work too cumbersome for use in the field and, apparently, a long interval before its completion.

\section{W. B. TuRriLl.}

\section{BLOOD CELLS OF AN INSECT}

T. FRANKLIN YAEGER of the U.S. Bureau of Entomology and Plant Quarantine (J.Agric. Research, 71, I ; 1945) has prepared a very detailed paper on this subject. Under the title of "The Blood Picture of the Southern Armyworm (Prodenia eridania)", the hæmocytes of this species of caterpillar are described, identified and classified. Also their incidence and changes at different stages in the development of the insect were noted. The blood cells or hæmocytes of insects, it may be added, are analogous to the leucocytes of vertebrates and form part of the defence mechanism against bacteria and other foreign bodies. There is evidence that the functions of these cells may be changed by the action of insecticides, but little progress is likely to be made as regards this problem until we know more about insect hæmocytes in general.

The author claims that in the southern armyworm the blood cells fall into ten classes, which he sub. divides into no fewer than thirty-two different types. He finds that existing systems of blood-cell classifica. tion are too far simplified to be of much help in identifying the hrmocytes of the armyworm. The early caterpillar is characterized by the predominance of primitive and perhaps embryonic types of blood cells. The late caterpillar has a marked development of special larval hæmocytes which reach their maximum in numbers and development about the beginning of pupation and disappear during the pupal stage. The imago is characterized by the development of the imaginal hæmocytes. The interrelationships of the different types and classes of blood cells are discussed and displayed in a schematic diagram.

The known functions of these various cells are summarized by the author as follows: (1) phagocytosis, (2) participation in hæmolymph coagulation, (3) agglutination in vivo, including the formation of capsules, (4) plastid formation, (5) eruption or sudden liberation of material into the plasma under certain conditions, and (6) glycogen storage. The paper is illustrated by numerous colour photographs (Koda. chrome) of preparations made of smears stained with Wright's blood stain. In almost all cases a $93 \times$ objective (oil immersion) and a $10 \times$ ocular were used. 